\title{
COVID-19 and human milk: SARS-CoV-2, antibodies, and neutralizing capacity
}

Ryan M. Pace, $\mathrm{PhD}^{1^{*}}$, Janet E. Williams, $\mathrm{PhD}^{2^{*}}$, Kirsi M. Järvinen, MD PhD ${ }^{3}$, Mandy B. Belfort, MD $\mathrm{MPH}^{4}$, Christina D.W. Pace, BS ${ }^{1}$, Kimberly A. Lackey, $\mathrm{PhD}^{1}$, Alexandra C. Gogel, BS ${ }^{1}$, Phuong Nguyen-Contant, $\mathrm{PhD}^{5}$, Preshetha Kanagaiah, $\mathrm{BS}^{5}$, Theresa Fitzgerald, $\mathrm{BS}^{5}$, Rita Ferri, $\mathrm{BA}^{3}$, Bridget Young, $\mathrm{PhD}^{3}$, Casey Rosen-Carole, $\mathrm{MD}^{3}$, Nichole Diaz, BS ${ }^{3}$, Courtney L. Meehan, $\mathrm{PhD}^{6}$, Beatrice Caffe, $\mathrm{BA}^{6}$, Mark Y. Sangster, $\mathrm{PhD}^{5}$, David Topham, $\mathrm{PhD}^{5}$, Mark A. McGuire, $\mathrm{PhD}^{2}$, Antti Seppo, $\mathrm{PhD}^{3 \#}$, Michelle K. McGuire, $\mathrm{PhD}^{1 \#}$

${ }^{1}$ Margaret Ritchie School of Family and Consumer Sciences, University of Idaho, Moscow, ID 83844; ${ }^{2}$ Department of Animal, Veterinary, and Food Sciences, University of Idaho, Moscow, ID 83844;

${ }^{3}$ Department of Pediatrics, Division of Allergy and Immunology, University of Rochester School of Medicine and Dentistry, Rochester, NY 14642;

${ }^{4}$ Department of Pediatric Newborn Medicine, Brigham and Women's Hospital and Harvard Medical School, Boston, MA 02115;

${ }^{5}$ David H. Smith Center for Vaccine Biology and Immunology, Department of Microbiology and Immunology, University of Rochester Medical Center, Rochester, NY 14642;

${ }^{6}$ Department of Anthropology, Washington State University, Pullman, WA 99164

${ }^{\star}$ Drs. Pace and Williams contributed equally to this article.

${ }^{\#}$ Corresponding authors:

Antti Seppo, antti seppo@urmc.rochester.edu;

Michelle K. McGuire, smcguire@uidaho.edu 
medRxiv preprint doi: https://doi.org/10.1101/2020.09.16.20196071; this version posted September 18, 2020. The copyright holder for this

preprint (which was not certified by peer review) is the author/funder, who has granted medRxiv a license to display the preprint in perpetuity.

It is made available under a CC-BY-NC-ND 4.0 International license .

\section{Abstract}

Background: It is not known whether SARS-CoV-2 can be transmitted from mother to infant during breastfeeding, and if so whether the benefits of breastfeeding outweigh this risk. This study was designed to evaluate 1) if SARS-CoV-2 RNA can be detected in milk and on the breast of infected women, 2) concentrations of milk-borne anti-SARS-CoV-2 antibodies, and 3) the capacity of milk to neutralize SARS-CoV-2 infectivity.

Methods: We collected 37 milk samples and 70 breast swabs (before and after breast washing) from 18 women recently diagnosed with COVID-19. Samples were analyzed for SARS-CoV-2 RNA using RT-qPCR. Milk was also analyzed for $\lg A$ and $\lg G$ specific for the nucleocapsid protein, receptor binding domain (RBD), S2 subunit of the spike protein of SARS-CoV-2, as well as 2 seasonal coronaviruses using ELISA; and for its ability to neutralize SARS-CoV-2.

Results: We did not detect SARS-CoV-2 RNA in any milk sample. In contrast, SARS-CoV-2 RNA was detected on several breast swabs, although only one was considered conclusive. All milk contained SARS-CoV-2-specific $\lg A$ and $\lg G$, and levels of anti-RBD $\lg A$ correlated with SARS-CoV-2 neutralization. Strong correlations between levels of IgA and IgG to SARS-CoV-2 and seasonal coronaviruses were noted.

Conclusions: Our data do not support maternal-to-child transmission of SARS-CoV-2 via milk; however, risk of transmission via breast skin should be further evaluated. Importantly, milk produced by infected mothers is a source of anti-SARS-CoV-2 $\lg A$ and $\lg G$ and neutralizes SARS-CoV-2 activity. These results support recommendations to continue breastfeeding during mild-to-moderate maternal COVID-19 illness.

Key words: breastfeeding | breastmilk | COVID-19 | human milk | SARS-CoV-2 | antibodies | neutralizing capacity 
medRxiv preprint doi: https://doi.org/10.1101/2020.09.16.20196071; this version posted September 18, 2020. The copyright holder for this preprint (which was not certified by peer review) is the author/funder, who has granted medRxiv a license to display the preprint in perpetuity.

It is made available under a CC-BY-NC-ND 4.0 International license .

\section{Introduction}

The global spread of severe acute respiratory virus 2 (SARS-CoV-2), the causative agent of coronavirus disease 2019 (COVID-19), has led to concerns over mother-to-child transmission, including via breastfeeding. Several studies have reported the presence of SARS-CoV-2 RNA in human milk, ${ }^{1-4}$ whereas others have not ${ }^{5-9}$ (Table S1). Most previous studies are limited because they followed only a few participants, were cross-sectional, and/or failed to report how milk was collected and/or analyzed. Thus, considerable uncertainty remains regarding whether human milk is capable of transmitting SARS-CoV-2 from mother to infant.

This paucity of rigorous methodology combined with inconsistency of viral RNA detection across studies has led to conflicting and changing recommendations regarding temporary separation of infants from mothers with COVID-19 and regarding whether infants should nurse directly at the breast or receive expressed milk from a bottle. ${ }^{10-13}$ Alongside the uncertainty about the risks of breastfeeding in the context of maternal COVID-19, it is well established that breastfeeding reduces the risk of myriad short- and long-term infectious and noninfectious conditions. ${ }^{14}$ Further, even a short delay in initiation of breastfeeding can interfere with the establishment of lactation ${ }^{15}$ and increase risks of infant morbidity and mortality. ${ }^{16-18}$

Many of the health-promoting effects of breastfeeding are due to the provision of passive immunity via immunoglobulins and other bioactive factors (e.g., lactoferrin), and previous studies have shown that milk-borne antibodies are produced in response to viral infection. ${ }^{19-22}$ However, few studies have examined the presence of antibodies to SARS-CoV-2 in human milk. ${ }^{23,24}$ In one recent study, milk from 12 of 15 women previously infected with SARS-CoV-2 contained IgA that was reactive to the receptor binding domain (RBD) of the SARS-CoV-2 spike protein. ${ }^{24}$ They also reported that antibodies in milk from previously infected women and milk collected prior to December 2019 (prepandemic) exhibited low-level cross-reactivity to RBD. However, levels of secretory IgA with reactivity to RBD were higher in milk from previously infected women. Cross-reactivity of antibodies in serum samples collected from healthy 
medRxiv preprint doi: https://doi.org/10.1101/2020.09.16.20196071; this version posted September 18, 2020. The copyright holder for this

It is made available under a CC-BY-NC-ND 4.0 International license .

individuals and those infected with seasonal human non-SARS coronaviruses (sCoV) have also been reported. ${ }^{25}$ This cross-reactivity is thought to stem from homology of the spike protein of sCoVs and SARS-CoV-2. The extent to which milk-borne antibodies have cross-reactivity to sCoV and whether these cross-reactive antibodies are associated with neutralization of SARSCoV-2 is currently not known. ${ }^{26}$

The primary objective of this study was to determine whether SARS-CoV-2 can be detected in milk produced by, and on the breast skin of, women recently diagnosed with COVID19 utilizing rigorous collection and analytical techniques. We also aimed to quantify anti-SARSCoV-2 IgA and $\lg G$ in milk and the capacity of milk to neutralize SARS-CoV-2. Because subclinical mastitis has been associated with higher viral loads in milk ${ }^{27}$, we also documented sodium-to-potassium ratios $(\mathrm{Na} / \mathrm{K})$ in milk, a biomarker of subclinical mastitis.

\section{Methods}

Experimental design and clinical data collection. This prospective study was carried out using a repeated-measures, longitudinal design. To be eligible, women needed to be $\geq 18$ years of age, lactating, and have received a positive test result for COVID-19 in the previous 8 days. Subjects were recruited through social media; word-of-mouth; and assistance of national maternal and child health organizations and local hospitals. All participants gave informed consent, and procedures were approved by the Institutional Review Boards at the University of Idaho (20-056, 20-060), the University of Rochester Medical Center (1507), and Brigham and Women's Hospital (2020P000804). Surveys were administered by telephone to ascertain timing of maternal/infant COVID-19 symptoms, reproductive history, breast health, breastfeeding practices, demographics, and anthropometrics.

Milk and breast swabs. All collection kits were assembled aseptically by study personnel wearing masks and gloves and were individually packaged to reduce potential contamination. Mothers were instructed in clean techniques to obtain samples, including use of gloves and 
medRxiv preprint doi: https://doi.org/10.1101/2020.09.16.20196071; this version posted September 18, 2020. The copyright holder for this

It is made available under a CC-BY-NC-ND 4.0 International license .

masks. Milk and swabs of the nipple/areola ("breast swabs") were either self-collected in participants' homes (with virtual assistance provided by study personnel), or at a hospital (participants $\mathrm{Q}$ and $\mathrm{R}$ were admitted to the postpartum unit at the time of sample collection).

Breast swabs were collected before and after washing the breast with soap and water and prior to milk collection. Women collected up to $30 \mathrm{~mL}$ of milk using the provided sterile manual breast pump (Harmony, Medela) and sterile collection containers. Details regarding sample collection are provided in the Supplemental Appendix.

Following collection, samples were immediately frozen in the subject's freezer until shipped in a cooler containing frozen cold packs to the University of Idaho (UI) or University of Rochester Medical Center (URMC). Samples collected from subjects $Q$ and $R$ were frozen at $80^{\circ} \mathrm{C}$ and shipped on dry ice to UI. Once received, samples were processed immediately for RNA extraction and/or stored at $-80^{\circ} \mathrm{C}$ until further analysis. As needed, samples were shipped on dry ice between UI and URMC. Milk samples collected from 10 healthy women located in the Rochester, NY area for general assay development purposes prior to December 2019 were used as prepandemic control samples.

SARS-CoV-2 RNA. Details related to RNA extraction and assay validation are provided in the Supplemental Appendix. Briefly, RNA was extracted from milk (both at UI and URMC), breast swabs (UI), and extraction controls (both at UI and URMC) using the Quick-DNA/RNA Viral MagBead kit (Zymo Research, Irvine, CA) with addition of the DNase I treatment on extracted nucleic acids following the manufacturer's protocol. Detection of SARS-CoV-2 viral RNA in milk was independently determined in both UI and URMC laboratories using the CDCdesigned 2019-nCoV RT-qPCR assay ${ }^{28}$, validated in both laboratories for use with human milk. Per the CDC protocol, samples with Ct values $<40$ were considered positive.

Sodium and potassium. For milk samples with sufficient volume (33 of 37), sodium (Na) and potassium $(\mathrm{K})$ concentrations were quantified in $200 \mu \mathrm{L}$ of milk using LAQUAtwin ion selective meters (Na-11 and K-11, respectively; Horiba Ltd., Kyoto). Prior to use, each meter 
medRxiv preprint doi: https://doi.org/10.1101/2020.09.16.20196071; this version posted September 18, 2020. The copyright holder for this preprint (which was not certified by peer review) is the author/funder, who has granted medRxiv a license to display the preprint in perpetuity.

It is made available under a CC-BY-NC-ND 4.0 International license .

was conditioned and calibrated according to vender specifications. After each measurement, meters were rinsed with Nanopure water, wiped dry, and allowed to reach zero. A Na to K ratio $(\mathrm{Na} / \mathrm{K})>0.6$ was interpreted to indicate subclinical mastitis. ${ }^{29,30}$

Antibodies. Concentrations of milk-borne $\lg A$ and $\lg G$ reactive to the SARS-CoV-2 spike (both S2 subunit and RBD) and nucleocapsid (N) proteins and spike proteins of seasonal coronaviruses 229E and OC43 were measured in milk samples by ELISA as previously described. ${ }^{31}$ Briefly, Nunc MaxiSorp 96-well plates (Thermo Fisher, Waltham, MA) were coated with optimized concentrations of antigens (1-5 $\mu \mathrm{g} / \mathrm{mL})$ overnight at $4^{\circ} \mathrm{C}$. Coated plates were blocked for $1 \mathrm{~h}$ before the addition of serial 2 -fold dilutions of samples. After a $2 \mathrm{~h}$ incubation at room temperature, plates were washed and bound IgG and IgA were detected with alkaline phosphatase-conjugated anti-human IgG (clone MT78; Mabtech, Stockholm, Sweden) and antihuman $\lg$ A. Bound antigen-specific antibodies were detected by adding p-nitrophenyl phosphate substrate (Thermo Fisher). Absorbance was read at $405 \mathrm{~nm}$ after color development. A weightbased concentration method was used to assign antigen-specific antibody titers in test samples. ${ }^{31,32}$

SARS-CoV-2 neutralization. The neutralizing activity of milk against SARS-CoV-2 was measured by microneutralization (MN) assay. Briefly, duplicates of delipidated milk were serially diluted 2-fold in virus diluent and incubated with 100 TCID50 of SARS-CoV-2 virus (Hong Kong/VM20001061/2020 isolate) in 96-well flat-bottomed plates for $1 \square \mathrm{h}$ at $37^{\circ} \mathrm{C}$. After incubation, Vero E6/TMPRSS2 cells (kindly provided by Yoshihiro Kawaoka, National Institute of Infectious Diseases, Japan; 25,000 cells/well) ${ }^{33}$ were added to the virus/sample mixtures. Plates were incubated for $48 \mathrm{~h}$ at $37^{\circ} \mathrm{C}$, when a cytopathic effect was evident in virus-only control wells. Cells were then fixed with $6 \%$ paraformaldehyde for $30 \mathrm{~min}$ and washed and stained with crystal violet for $1 \mathrm{~h}$. The MN titer was identified as the highest dilution of sample that showed $50 \%$ neutralization based on the appearance of the stained cell monolayer as compared with the virus control well. 
medRxiv preprint doi: https://doi.org/10.1101/2020.09.16.20196071; this version posted September 18, 2020. The copyright holder for this

It is made available under a CC-BY-NC-ND 4.0 International license .

Statistical analysis. Except where noted, all statistical analyses were performed using $\mathrm{R}$ (version 3.6.1). Statistical testing of antibody concentrations and MN titers were performed using parametric tests on log-transformed data. Linear regression was performed using either $\operatorname{Im}()$ or $\operatorname{rm}()$ function in $\mathrm{R}$ as appropriate.

\section{Results}

Participants and samples collected. Eighteen women with a recent diagnosis of laboratory-confirmed COVID-19 participated in the study. On average, women were $34.2 \pm 4.7$ yr old and $6.8 \pm 7.8$ mo postpartum. Additional characteristics of study participants and their infants are presented in Table 1. Of the 18 participants, all but three had symptoms related to COVID-19, with the most common being loss of smell/taste (11/18), headache (10/18), and fatigue (7/18) (Fig. 1A). Two of the three participants who were asymptomatic throughout the course of the study were initially tested for routine surveillance prior to being admitted to the hospital for labor and delivery (participants $L$ and $M$ ); while the other (participant $N$ ) was tested due to a potential occupational exposure. Two of six infants tested for COVID-19 had a positive result.

We collected and analyzed 37 milk samples (Fig. 1B). Repeated samples were collected from 14 participants. Among women with symptoms at enrollment or who developed symptoms during the study, 6 provided samples within the first week of symptom(s), with the earliest sample collected $2 \mathrm{~d}$ prior to symptom(s) onset. This participant was initially tested for COVID19 because of a close family exposure even though she was not currently symptomatic. Across all participants, the first sample was collected on average $12.0 \pm 8.9 \mathrm{~d}$ after symptom onset. Breast swabs were collected from 15 women, although participant F collected swabs prior to breast cleaning and then after milk collection (rather than before milk collection) (Table S2).

SARS-CoV-2 RNA and Na/K in milk. None of the milk contained detectable SARS-CoV2 RNA. RT-qPCR findings were not modified by the milk fraction tested (i.e., whole milk or 
medRxiv preprint doi: https://doi.org/10.1101/2020.09.16.20196071; this version posted September 18, 2020. The copyright holder for this

preprint (which was not certified by peer review) is the author/funder, who has granted medRxiv a license to display the preprint in perpetuity.

It is made available under a CC-BY-NC-ND 4.0 International license.

supernatant), and results were concordant between laboratories. Milk $\mathrm{Na} / \mathrm{K}$ ratios ranged from 0.2 to $10.9(0.5$, median) with $12(36 \%)$ samples having an elevated ratio $(>0.6)$, suggesting subclinical mastitis in 9 participants.

SARS-CoV-2 RNA on breast swabs. Of the 70 swabs tested, eight had evidence of SARS-CoV-2 RNA (Table S2). One swab collected prior to breast washing tested conclusively positive with $\mathrm{Ct}$ values $<40$ in both duplicates for both the N1 and N2 targets. Two additional swabs collected prior to breast washing had detectable signal in both duplicates for one of the SARS-CoV-2 targets, but only one duplicate for the other target. Five swabs had detectable signal in just one duplicate for one target.

Anti-SARS-CoV-2 $\lg A$ and $\lg G$ in milk. Concentrations of anti-SARS-CoV-2 IgA were higher than those of IgG (Fig. 2A). Milk produced by women with COVID-19 had higher antiRBD $\lg A$ and $\lg G$ concentrations than milk collected from women before the pandemic ( $p=0.000015$ and $\mathrm{p}=0.00098$, respectively). This pattern was also evident for anti-S2 and anti-N $\lg G(p=0.0006$ and $p=0.000089$, respectively), but not $\lg A$. Aside from the fact that prepandemic milk contained higher levels of IgA to SCoV 229E than milk produced during the pandemic $(p=0.054)$, there was little difference between milk collected from study participants and prepandemic samples in terms of milk IgA and IgG to the full-length S proteins of SCoV $229 \mathrm{E}$ and OC43. Concentrations of IgA to SARS-CoV-2 and SCoV were correlated, particularly in milk produced by women with COVID-19 (Fig. 2B).

Neutralizing capacity of milk. A total of 21 of 34 milk samples $(62 \%)$ collected from women with COVID-19 were found to neutralize SARS-CoV-2 infectivity in vitro. Although neutralization titers correlated with concentrations of $\lg$ A to all SARS-CoV-2 antigens tested (Fig. 3A and Fig. S1), in a regression model that included all antigen targets, only the SARSCoV-2 RBD had a significant $\beta$ ( $p=0.0125)$, consistent with neutralization primarily by anti-RBD antibodies. Furthermore, an analysis of sequential milk samples collected from study 
medRxiv preprint doi: https://doi.org/10.1101/2020.09.16.20196071; this version posted September 18, 2020. The copyright holder for this

It is made available under a CC-BY-NC-ND 4.0 International license .

participants identified increases in anti-RBD IgA concentrations that were associated with elevated MN titers (Fig. 3B).

\section{Discussion}

Although human milk is considered the best source of nutrition for most infants, the onset of the global COVID-19 pandemic and our lack of understanding on SARS-CoV-2 transmission has caused confusion around whether infected mothers should be temporarily separated from their infants, as well as whether breastfeeding should be initiated and/or continued during maternal COVID-19 illness. In this prospective study we collected milk and breast swabs from women with COVID-19 and tested them for the presence of SARS-CoV-2 RNA. We also analyzed the milk for IgA and IgG targeting SARS-CoV-2 and the ability of the samples to neutralize SARS-CoV-2 infectivity.

Using methods validated and replicated across two laboratories, and consistent with most previous reports, we did not detect SARS-CoV-2 RNA in any of the milk samples.

Although a single breast swab collected from the breast before it was cleaned was found conclusively to contain SARS-CoV-2 RNA, a swab collected after the breast was washed did not. It is noteworthy that several of the women in our study had evidence of subclinical mastitis, which has previously been shown to be positively related to milk RNA viral load in HIV-infected women. ${ }^{27}$ Nonetheless, we detected no SARS-CoV-2 in their milk. Together, our results suggest that milk may not act as a vehicle for mother-to-child transmission of SARS-CoV-2, although viral exposure via breast skin is possible. Our lack of detection of viral RNA on the breast after washing supports existing recommendations for women to take precautions during breastfeeding and/or expression of milk (e.g., practicing respiratory and hand hygiene, cleaning pump parts prior to and after use) to reduce the potential for viral transmission.

Importantly, we detected anti-SARS-CoV-2 antibodies in milk, primarily lgA but also lgG, albeit at lower concentrations than those reported for serum of actively infected patients. ${ }^{34}$ 
medRxiv preprint doi: https://doi.org/10.1101/2020.09.16.20196071; this version posted September 18, 2020. The copyright holder for this

It is made available under a CC-BY-NC-ND 4.0 International license .

Concentrations of anti-SARS-CoV- S2 antibodies correlated strongly with those of the other tested sCoV spike proteins in milk produced by study participants and those produced prior to the pandemic. This pattern of cross-reactivity may reflect structural similarity among the proteins, and likely reflects a recall response from prior exposure to sCoV. However, generation of RBD-reactive antibodies likely requires generation of new B-cell populations, because the RBD of the SARS-CoV-2 spike protein shares little sequence homology with other SCoVs.

While the detection of SARS-CoV-2 RNA in milk and/or on breast is of concern, it does not necessarily indicate presence of viable virus. In the only study that has assessed viability of SARS-CoV-2 in milk, a single milk sample positive for SARS-CoV-2 RNA did not contain replication-competent virus ${ }^{35}$. Unfortunately, in our study we were unable to determine viability of SARS-CoV-2 in any of the breast swabs positive for SARS-CoV-2 RNA because the entire sample was needed for RNA detection. Future studies should determine the viability of any SARS-CoV-2 found in milk and/or the breast.

Our study has several strengths, including the use of rigorous collection methods; close temporal proximity of sample collections to COVID-19 diagnosis; validation of analytical methods for human milk; replication of RT-qPCR analyses across laboratories; and analysis of both risks and benefits of milk constituents. We also acknowledge that this study has limitations. For instance, most samples were collected from women after onset of symptoms, limiting generalizability to pre-symptomatic women. Additionally, none of our participants was hospitalized due to COVID-19. As disease severity may be related to viral titer ${ }^{38}$, it is possible that milk produced by individuals with more severe COVID-19 could contain SARS-CoV-2. The short duration of the follow-up period also does not allow characterization of the durability of the milk IgA and IgG responses. Initial reports on serum IgG response may suggest a relatively short-lived response ${ }^{36,37}$, and no data exist on the presence of long-lived memory B-cells in context of SARS-CoV-2. Milk IgA, representing a mucosal response, may have its own pattern of durability. 
medRxiv preprint doi: https://doi.org/10.1101/2020.09.16.20196071; this version posted September 18, 2020. The copyright holder for this preprint (which was not certified by peer review) is the author/funder, who has granted medRxiv a license to display the preprint in perpetuity.

It is made available under a CC-BY-NC-ND 4.0 International license .

In summary, we did not detect SARS-CoV-2 RNA in milk collected from women with mild-to-moderate COVID-19. However, we demonstrated that milk contains anti-SARS-CoV-2 antibodies and that their concentrations are correlated with milk's ability to effectively neutralize SARS-CoV-2 infectivity. We found evidence of SARS-CoV-2 on the breasts of several women, but it is unclear whether this RNA reflects viable virus. Taken together with the well-documented benefits of breastfeeding to maternal and infant health, our data support recommendations to encourage breastfeeding in women with mild-to-moderate COVID-19 illness.

\section{Acknowledgements}

This study was funded by a grant from the Bill and Melinda Gates Foundation, in-kind support from Medela and Milk Stork, US National Institutes of Health (R01 HD092297-03, U01 Al131344-04S1), Washington State University Health Equity Research Center, and the University of Idaho Agricultural Experiment Station. 


\section{References}

1. Groß R, Conzelmann C, Müller JA, et al. Detection of SARS-CoV-2 in human breastmilk. Lancet 2020;395(10239):1757-8.

2. Buonsenso D, Costa S, Sanguinetti M, et al. Neonatal late onset infection with severe acute respiratory syndrome coronavirus 2. Am J Perinatol 2020;37(08):869-72.

3. Kirtsman M, Diambomba Y, Poutanen SM, et al. Probable congenital SARS-CoV-2 infection in a neonate born to a woman with active SARS-CoV-2 infection. CMAJ 2020;192(24):E647-50.

4. Tam PCK, Ly KM, Kernich ML, et al. Detectable severe acute respiratory syndrome coronavirus 2 (SARS-CoV-2) in human breast milk of a mildly symptomatic patient with coronavirus disease 2019 (COVID-19). Clin Infect Dis 2020;ciaa673.

5. Chen $\mathrm{H}$, Guo J, Wang C, et al. Clinical characteristics and intrauterine vertical transmission potential of COVID-19 infection in nine pregnant women: a retrospective review of medical records. Lancet 2020;395(10226):809-15.

6. Cui Y, Tian M, Huang D, et al. A 55-day-old female infant infected with 2019 novel coronavirus disease: Presenting with pneumonia, liver injury, and heart damage. J Infect Dis 2020;376:584-7.

7. Deng G, Zeng F, Zhang L, Chen H, Chen X, Yin M. Characteristics of pregnant COVID19 patients with liver injury. J Hepatol 2020;S0168-8278(20)30395-0.

8. Fan C, Lei D, Fang C, et al. Perinatal transmission of COVID-19 associated SARS-CoV2: Should we worry? Clin Infect Dis 2020;ciaa226.

9. Lackey KA, Pace RM, Williams JE, et al. SARS-CoV-2 and human milk: What is the evidence? Matern Child Nutr 2020;38(1):345.

10. Centers for Disease Control and Prevention. Evaluation and management considerations for neonates at risk for COVID-19 [Internet]. cdc.govcoronavirus-ncovhcpcaring-fornewborns.html. [cited 2020 Jul 15];Available from: https://www.cdc.gov/coronavirus/2019ncov/hcp/caring-for-newborns.html

11. World Health Organization. Breastfeeding and COVID-19: Scientific brief [Internet]. 2020. Available from: https://www.who.int/news-room/commentaries/detail/breastfeeding-andcovid-19

12. American Academy of Pediatrics. Policy statement: Breastfeeding and the use of human milk. Pediatrics 2012;129(3):e827-41.

13. American Academy of Pediatrics. Breastfeeding guidance post hospital discharge for mothers or infants with suspected or confirmed SARS-CoV-2 infection [internet]. 2020. Available from: https://services.aap.org/en/pages/2019-novel-coronavirus-covid-infections/clinical-guidance/breastfeeding-guidance-post-hospital-discharge/

14. Stuebe A. The risks of not breastfeeding for mothers and infants. Rev Obstet Gynecol 2009;2(4):222-31. 
15. Parker LA, Sullivan S, Krueger C, Mueller M. Association of timing of initiation of breastmilk expression on milk volume and timing of lactogenesis stage II among mothers of very low-birth-weight infants. Breastfeeding Med 2015;10(2):84-91.

16. Edmond KM, Zandoh C, Quigley MA, Amenga-Etego S, Owusu-Agyei S, Kirkwood BR. Delayed breastfeeding initiation increases risk of neonatal mortality. Pediatrics 2006;117(3):e380-6.

17. Smith ER, Locks LM, Manji KP, et al. Delayed breastfeeding initiation is associated with infant morbidity. J Pediatr 2017;191:57-62.e2.

18. NEOVITA Study Group. Timing of initiation, patterns of breastfeeding, and infant survival: Prospective analysis of pooled data from three randomised trials. Lancet Glob Health 2016;4(4):e266-75.

19. Fouda GG, Yates NL, Pollara J, et al. HIV-specific functional antibody responses in breast milk mirror those in plasma and are primarily mediated by $\lg \mathrm{G}$ antibodies. J Virol $2011 ; 85(18): 9555-67$.

20. Pollara J, McGuire E, Fouda GG, et al. Association of HIV-1 envelope-specific breast milk $\lg A$ responses with reduced risk of postnatal mother-to-child transmission of HIV-1. J Virol 2015;89(19):9952-61.

21. Tsutsumi H, Honjo T, Nagai K, Chiba Y, Chiba S, Tsugawa S. Immunoglobulin A antibody response to respiratory syncytial virus structural proteins in colostrum and milk. J Clin Microbiol 1989;27(9):1949-51.

22. Mazur NI, Horsley NM, Englund JA, et al. Breast milk prefusion F immunoglobulin $\mathrm{G}$ as a correlate of protection against respiratory syncytial virus acute respiratory illness. J Infect Dis 2019;219(1):59-67.

23. Dong $\mathrm{Y}$, Chi $\mathrm{X}$, Hai $\mathrm{H}$, et al. Antibodies in the breast milk of a maternal woman with COVID-19. Emerg Microbes Infect 2020;9(1):1467-9.

24. Fox A, Marino J, Amanat $F$, et al. Evidence of a significant secretory-lgA-dominant SARS-CoV-2 immune response in human milk following recovery from COVID-19. medRxiv 2020;2020.05.04.20089995. preprint.

25. Hicks J, Klumpp-Thomas C, Kalish H, et al. Serologic cross-reactivity of SARS-CoV-2 with endemic and seasonal Betacoronaviruses. medRxiv 2020;2020.06.22.20137695. preprint.

26. Centers for Disease Control and Prevention. Care for breastfeeding women [Internet]. cdc.govbreastfeedingbreastfeeding-special-circumstancesmaternal-or-infantillnessescovid--and-breastfeeding.html. [cited 2020 Apr 7];Available from: https://www.cdc.gov/breastfeeding/breastfeeding-special-circumstances/maternal-orinfant-illnesses/covid-19-and-breastfeeding.html

27. Willumsen JF, Filteau SM, Coutsoudis A, et al. Breastmilk RNA viral load in HIV-infected South African women: effects of subclinical mastitis and infant feeding. AIDS 2003;17(3):407-14. 
28. Lu X, Wang L, Sakthivel SK, et al. US CDC Real-Time reverse transcription PCR panel for detection of severe acute respiratory syndrome coronavirus 2. Emerg Infect Dis $2020 ; 26(8): 1654-65$.

29. Filteau SM, Lietz G, Mulokozi G, Bilotta S, Henry CJK, Tomkins AM. Milk cytokines and subclinical breast inflammation in Tanzanian women: effects of dietary red palm oil or sunflower oil supplementation. Immunology 1999;97(4):595-600.

30. Li C, Solomons NW, Scott ME, Koski KG. Subclinical mastitis (SCM) and proinflammatory cytokines are associated with mineral and trace element concentrations in human breast milk. J Trace Elem Med Bio 2017;46:55-61.

31. Tesini BL, Kanagaiah P, Wang J, et al. Broad hemagglutinin-specific memory B cell expansion by seasonal influenza virus infection reflects early-life imprinting and adaptation to the infecting virus. J Virol 2019;93:e00169-19.

32. Quataert SA, Rittenhouse-Olson K, Kirch CS, et al. Assignment of weight-based antibody units for 13 serotypes to a human antipneumococcal standard reference serum, lot 89S(F). Clin Diagn Lab Immunol 2004;11(6):1064-9.

33. Matsuyama S, Nao N, Shirato K, et al. Enhanced isolation of SARS-CoV-2 by TMPRSS2expressing cells. Proc Natl Acad Sci USA 2020;117(13):7001-3.

34. Nguyen-Contant $P$, Embong AK, Kanagaiah $P$, et al. $S$ protein-reactive Ig $\mathrm{G}$ and memory $B$ cell production after human SARS-CoV-2 infection includes broad reactivity to the S2 subunit. bioRxiv 2020;2020.07.20.213298. preprint.

35. Chambers C, Krogstad P, Bertrand K, et al. Evaluation for SARS-CoV-2 in breast milk from 18 infected women. JAMA 2020;e2015580.

36. Long Q-X, Tang X-J, Shi Q-L, et al. Clinical and immunological assessment of asymptomatic SARS-CoV-2 infections. Nat Med 2020;26(8):1200-4.

37. Ibarrondo FJ, Fulcher JA, Goodman-Meza D, et al. Rapid decay of anti-SARS-CoV-2 antibodies in persons with mild Covid-19. N Engl J Med 2020;NEJMc2025179.

38. Liu Y, Yan L-M, Wan L, et al. Viral dynamics in mild and severe cases of COVID-19. Lancet Infect Dis 2020;20(6):656-7. 
medRxiv preprint doi: https://doi.org/10.1101/2020.09.16.20196071; this version posted September 18, 2020. The copyright holder for this preprint (which was not certified by peer review) is the author/funder, who has granted medRxiv a license to display the preprint in perpetuity.

It is made available under a CC-BY-NC-ND 4.0 International license .

\section{Figures and Tables}

Table 1. Study participant characteristics.

Figure 1. Overview of participants' COVID-19 symptoms, and COVID-19 diagnostic testing and sampling.

Figure 2. Milk antibody concentrations.

Figure 3. Correlations of milk IgA concentrations with microneutralization titers. 


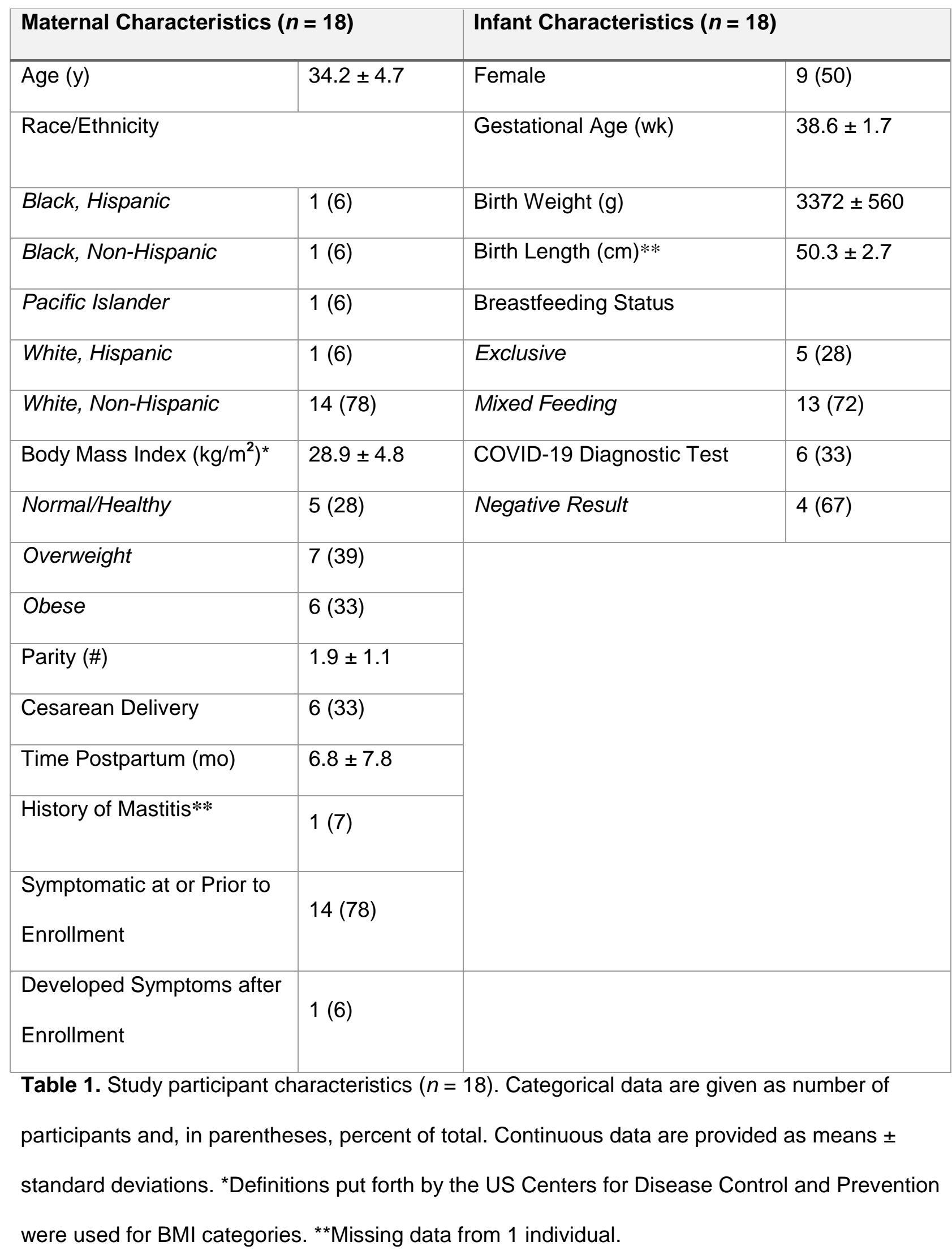



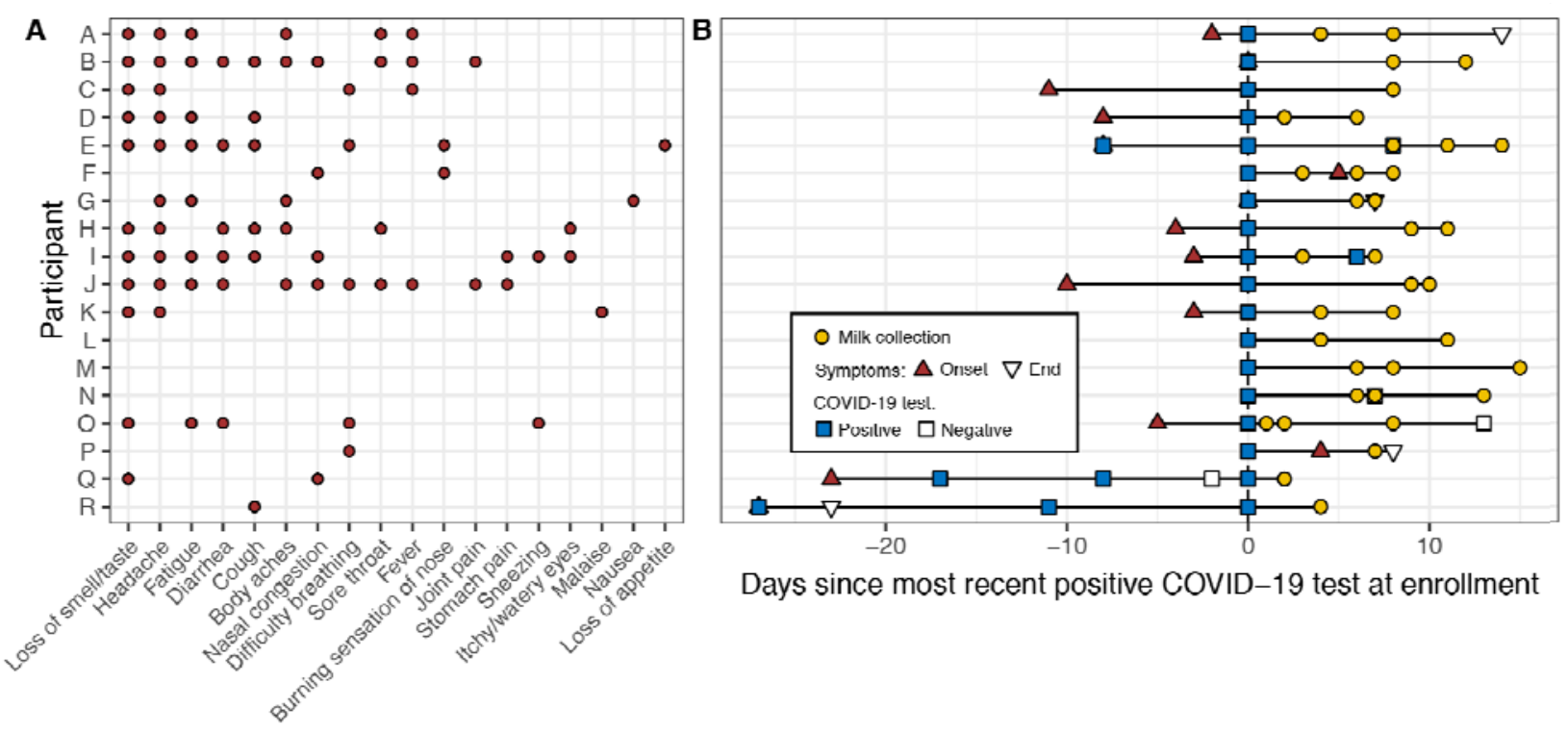

Days since most recent positive COVID-19 test at enrollment

Figure 1. Overview of participants' (A) COVID-19 symptoms, and (B) COVID-19 diagnostic

testing and sampling. In panel B, the time "0" represents the most recent positive COVID-19

test at enrollment. Participants E, I, N, O, Q, and R had additional COVID-19 tests performed;

all were positive except for N's and O's second test and Q's third test which were negative

(open squares). Participants $\mathrm{L}, \mathrm{M}$, and $\mathrm{N}$ were asymptomatic during the study period, and

participants $\mathrm{F}$ and $\mathrm{P}$ developed symptoms after first testing positive. 
A

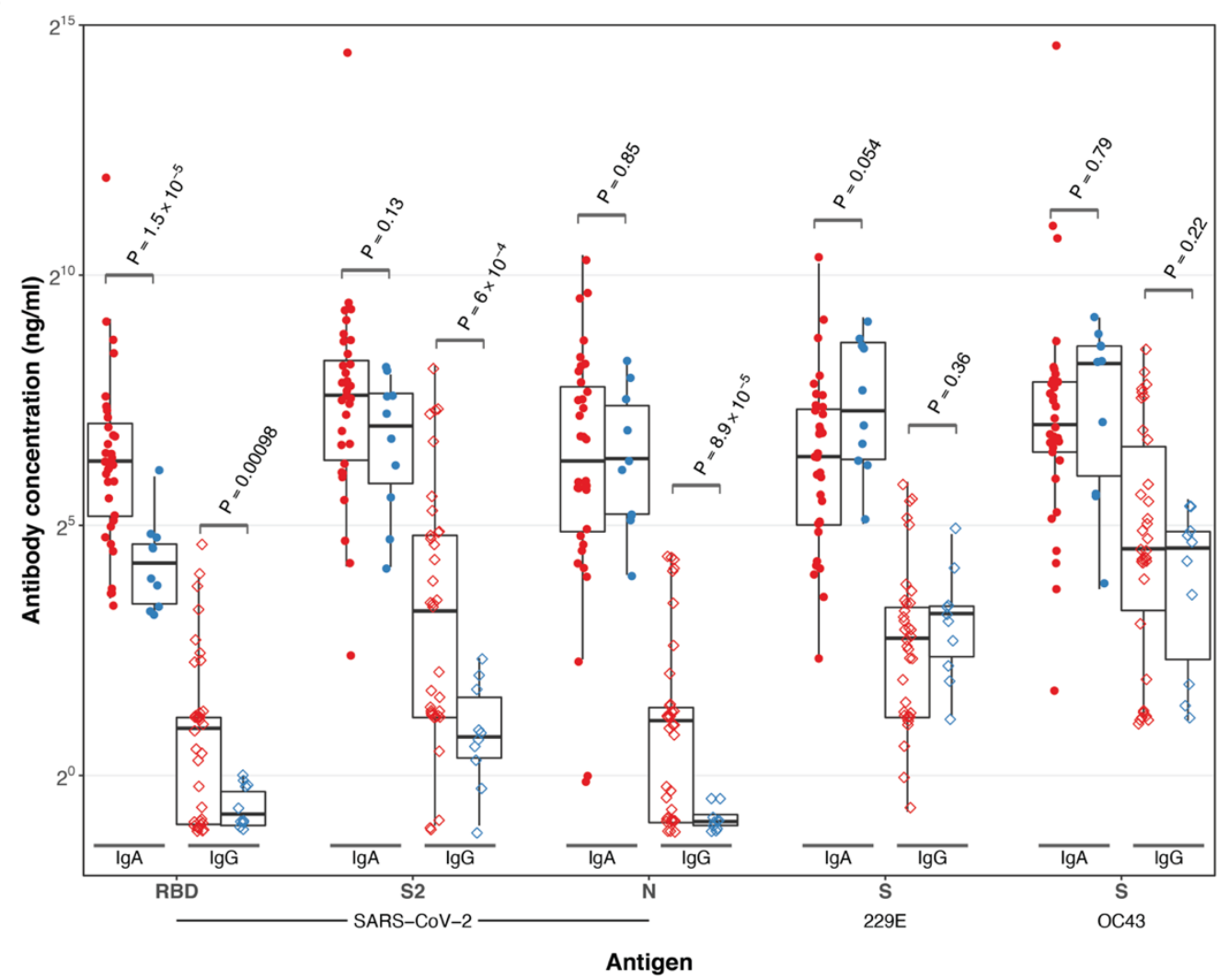

Subject

- infected

- prepandemic control

B

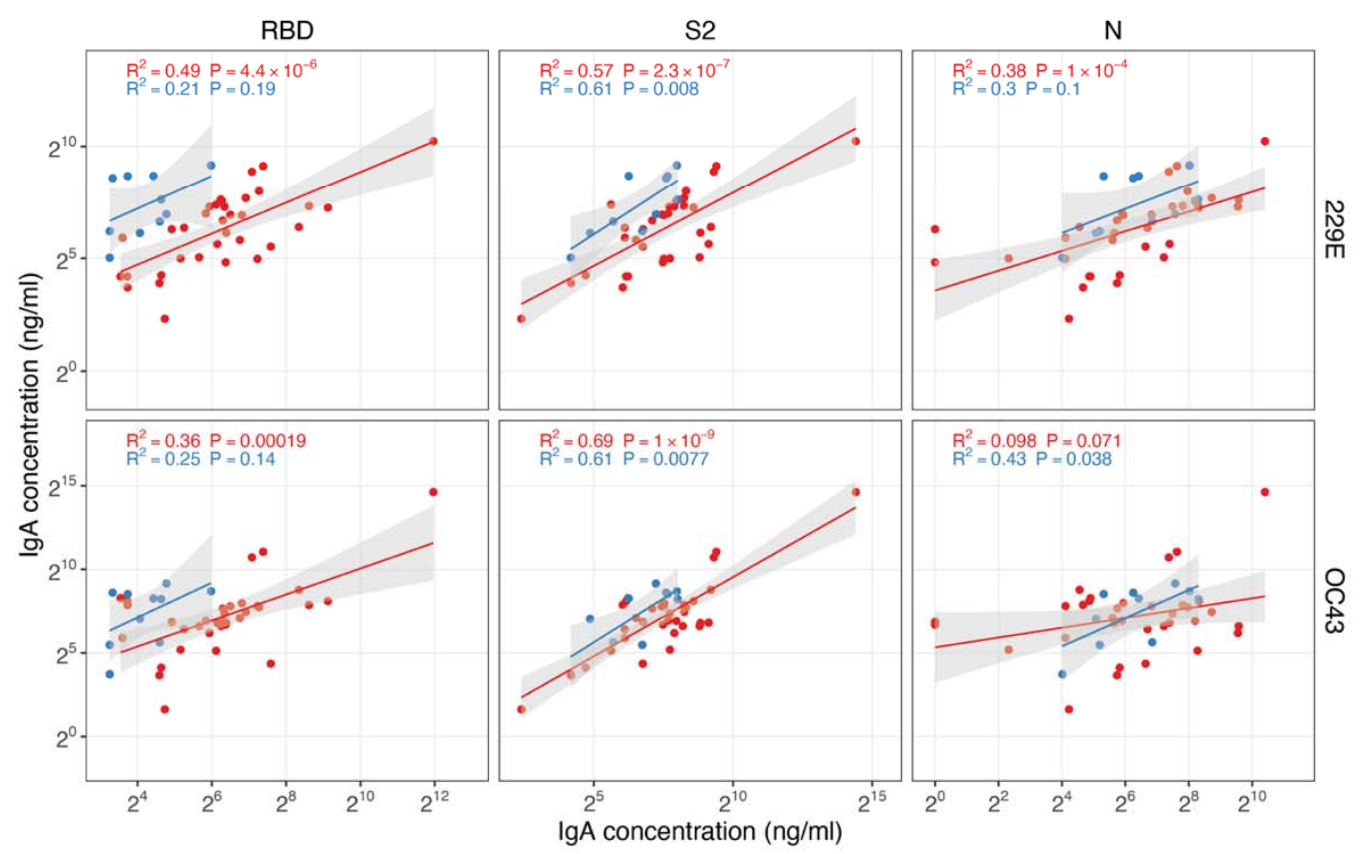

Figure 2. Milk antibody concentrations. Panel A shows IgA (filled circles) and IgG (open diamonds) to coronavirus antigens in milk produced by COVID-19 (red) infected and healthy, 
medRxiv preprint doi: https://doi.org/10.1101/2020.09.16.20196071; this version posted September 18, 2020. The copyright holder for this preprint (which was not certified by peer review) is the author/funder, who has granted medRxiv a license to display the preprint in perpetuity. It is made available under a CC-BY-NC-ND 4.0 International license .

prepandemic (blue) women. Antibody concentrations were measured using ELISA specific to the RBD and S2 domains of the spike and nucleocapsid $(\mathrm{N})$ proteins of SARS-CoV-2, and S proteins from human coronaviruses 229E and OC43. Panel B shows correlations between IgA concentrations to SARS-CoV-2 antigens RBD, S2, and $\mathrm{N}$ and $\lg A$ concentrations to $S$ proteins from 229E and OC43 in milk produced by COVID-19 infected (red) and healthy, prepandemic (blue) women. A linear model was fit to log transformed $\lg A$ concentrations to give $r$-squared and p-values as indicated. Model prediction (red or blue line as above) is shown with the $95 \%$ confidence interval (grey shading). 

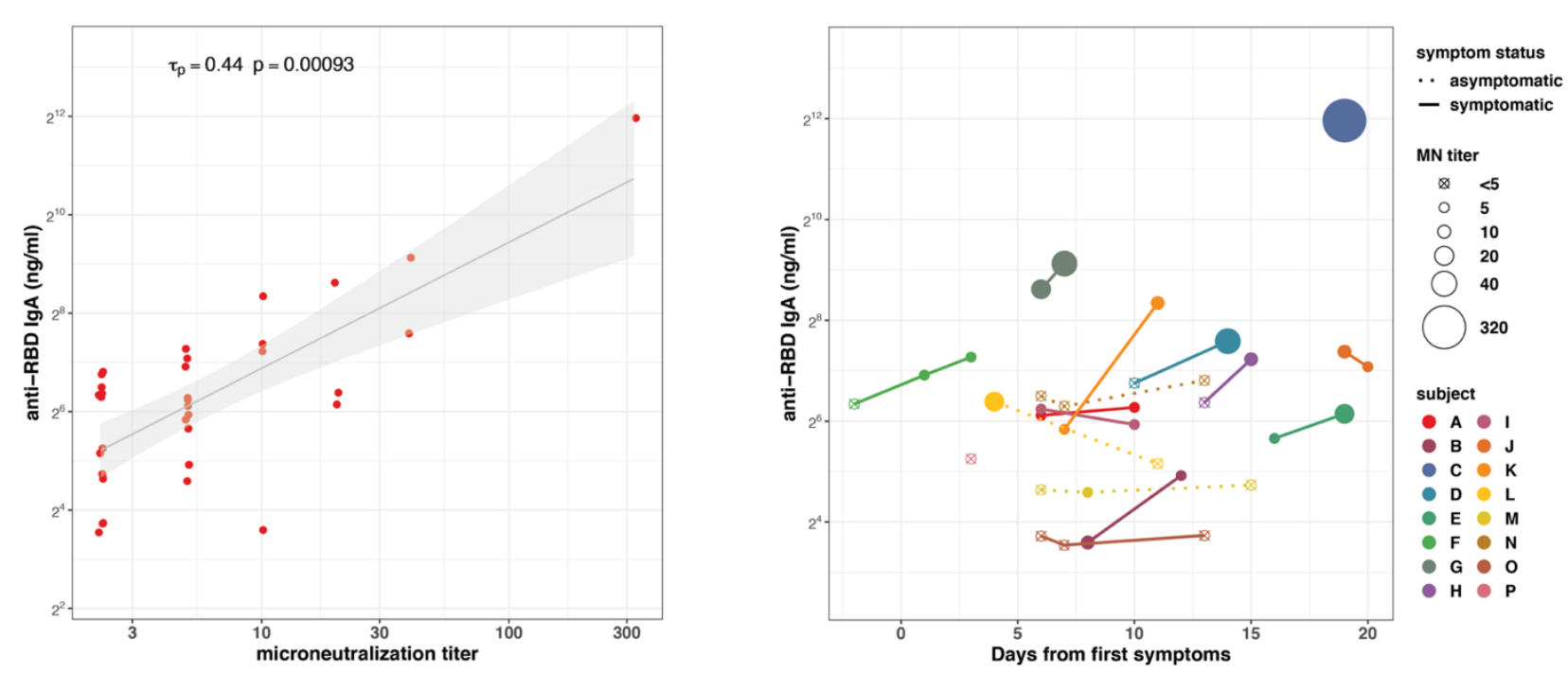

Figure 3. Correlation of milk IgA concentrations with microneutralization titers. Panel A shows correlation between concentrations of IgA specific to SARS-CoV-2 RBD and microneutralization titers in milk produced by COVID-19 infected women. Kendall rank correlation $\tau_{\mathrm{p}}$ and associated $\mathrm{p}$-value as shown. A linear model was fit to $\log$ transformed $\lg \mathrm{A}$ concentrations and $\mathrm{MN}$ titers and is shown (black line) with 95\% confidence interval (grey shading) for visualization purposes only. Panel B shows anti-RBD IgA concentrations and microneutralization titers over time. Each color and corresponding point or set of connected points represent one participant. Time of collection is indicated on x-axis and antibody concentration on $\mathrm{y}$-axis. MN titer of each sample is reflected in the size of each point. Asymptomatic participants are indicated using a dotted line connecting points. 